\title{
EFEITOS DA DEGRADAÇÃO AMBIENTAL NO ESPAÇO NATURAL DA PRAIA DE AJURUTEUA (PA): Percepção dos Pescadores Locais
}

\author{
Fabrício Khoury Rebello ${ }^{1}$ \\ Francisco Pereira Smith Junior ${ }^{2}$ \\ Maria Lúcia Bahia Lopes ${ }^{3}$ \\ Rodrigo Fraga Garvão ${ }^{4}$ \\ Rosália do Socorro da Silva Corrêa ${ }^{5}$
}

\begin{abstract}
RESUMO
A exploração desordenada dos recursos naturais vem gerando um quadro de degradação ambiental que atinge vários ecossistemas costeiros brasileiros. Neste contexto, a pesquisa visa identificar as mudanças ocorridas no espaço natural da praia de Ajuruteua na percepção dos pescadores da Vila dos Pescadores localizada na Ilha de Ajuruteua. Para uma maior integração na análise ambiental, a questão foi tratada com destaque para os principais atores e as interações entre o quadro social e o meio natural.
\end{abstract}

Palavras-chave: pescador, meio ambiente, paisagem, percepção, Ajuruteua

\begin{abstract}
The uncontrolled exploitation of natural resources has been generating a picture of environmental degradation that affects several Brazilian coastal ecosystems. In this context, the research aims to identify significant changes in the natural space of Ajuruteua beach in the perception of the fishermen village of fishermen located in Ajuruteua Island. For further integration in the environmental analysis, the issue was addressed with emphasis on the main actors and the interactions between the membership and the natural environment.
\end{abstract}

Keywords: fisherman, environment, landscape

Recebido em: 21/04/ 2017

Aprovado em: 10/05/2017

\section{INTRODUÇÃO}

A sociedade contemporânea mundial talvez vivencie a pior de todas as suas crises, a do meio ambiente, a exploração dos recursos naturais de forma descontrolada, altera a vida na terra, destrói sua fauna e a flora e compromete todo o seu equilíbrio ecológico. Ao longo da evolução da humanidade, o homem sempre atuou como agente modificador de processos naturais, causando impactos irreversíveis e com consequências trágicas.

\footnotetext{
${ }^{1}$ Professor da Universidade Federal Rural da Amazônia (UFRA). E-mail: rebello@ hotmail.com

${ }^{2}$ Professor Adjunto III da Universidade Federal do Pará, campus Bragança. E-mail: fsmith@ufpa.br

${ }^{3}$ Doutora em economia aplicada pela Universidade Federal de Viçosa- UFV. E-mail: luciabahia@ uai.com.br

${ }^{4}$ Professor da Universidade Federal Rural da Amazônia (UFRA), mestre em Desenvolvimento e Meio Ambiente Urbano. E-mail: rodrigofragabh@gmail.com

${ }^{5}$ Doutora em sociologia pela Universidade Federal da Paraíba-UFPB. E-mail: rosallya9@ @otmail.com
} 
Se o ser humano falhar com o meio ambiente e as empresas juntamente se retirarem de qualquer responsabilidade sem cobranças por parte do governo, os impactos ambientais serão cada vez maiores, pois além de prejuízos a natureza, existirão também prejuízos de caráter econômico e social.

Durante a vida na terra, vários foram os episódios e os lugares onde a interferência humana tem causado alterações no meio ambiente. $\mathrm{O}$ século $\mathrm{XX}$ foi marcado por grandes catástrofes ambientais, dentre tantas está a cidade de Kyshtym na Rússia, quando a mesma foi tomada por um vazamento radioativo devido ao sistema de resfriamento de um dos reatores da usina de Mayak ter parado de funcionar. Assim como ocorreu nos Estados Unidos, quando também houve um vazamento de óleo cru no mar de Prince William Sound, da mesma forma que se destaca o vazamento químico no Golfo Pérsico no Kuwait em 1991.

O Brasil está entre os países que mais agride a natureza, vivenciou um dos piores crimes contra o meio ambiente, esse episódio ficou conhecido como o vazamento químico de Cubatão, ocorrido em São Paulo, na década de 80, quando vazaram litros de gasolina de um oleoduto da Petrobras. Além desse crime ambiental, destaca-se também o rompimento das barragens Samarco ${ }^{6}$ em Minas Gerais, quando uma avalanche de lama química avançou pelos estados de Minas Gerais e Espírito Santo até alcançar o mar do litoral capixaba, quase atingindo o arquipélago de Abrolhos na Bahia. Dentre tantas regiões brasileiras, a área costeira do pais também sofre com a interferência do homem. Neste contexto, chama-se atenção para o litoral amazônico, mais precisamente, a costa paraense, que vem nos últimos anos passando por alterações na sua paisagem e na vida local dos seus habitantes, este será o cenário de pesquisa deste trabalho.

O estado do Pará por ter características peculiares se destaca por sua diversidade territorial, com um litoral que mistura águas dos rios amazônicos ao oceano atlântico. Como faz parte da região amazônica, seu território é marcado pela grandiosidade de rios e vasto litoral, isso faz com que exista uma grande extensão de mangue e uma variedade de espécies de peixes na região.

O nordeste do estado do Pará, desde a década de 1970, vem sofrendo alterações com o aumento da pressão demográfica e incremento da especulação imobiliária. Estando em área litorânea belezas exuberantes, caracterizadas por várias praias, manguezais, rios e floresta tropical. Este quadro de beleza, ligado a possibilidade de lazer tem chamado a atenção da população local e turistas que buscam paz e tranquilidade nas férias e nos finais de semana.

\footnotetext{
${ }^{6}$ Mineradora brasileira fundada em 1977 e atualmente controlada através de uma joint-venture entre a Vale S.A. e a anglo-australiana BHP Billiton, cada uma com $50 \%$ das ações da empresa.
} 
Entretanto, muitas vezes, o avanço ao litoral tem ocorrido de forma desordenada, causando transformações ambientais sociais e culturais. Em algumas localidades, como a praia de Ajuruteua, atividades de subsistência tradicionais - como a pesca artesanal - vem sendo abandonada em função de atividades intensas de turismo, a presença de banhistas na praia, poluição, aliada ao avanço de construções na faixa de areia faz com que cada vez mais a atividade da pesca veja se tornar escasso seu principal produto, o pescado. Em função disso, a comunidade pesqueira local vê-se quase obrigada a abandonar sua atividade principal e acabam se "acomodando" com as ajudas de custo do governo federal, como bolsas e outros tipos de benefícios.

\section{MUDANÇAS NA PAISAGEM DA PRAIA: PERCEPÇÃO DOS PESCADORES}

$\mathrm{Na}$ atualidade as questões que dizem respeito ao meio ambiente e às relações sociedade e natureza fazem parte dos temas mais significativos do mundo moderno. As reflexões em torno da temática ambiental ainda fazem parte de uma discussão acadêmica que necessita adentrar a sociedade comum de forma efetiva e eficaz. Este, talvez seja um dos maiores desafios desta sociedade capitalista, que busca por preservar sem destruir e crescer sem poluir, desenvolver e garantir a existência de uma vida sustentável sem agredir o meio ambiente.

O cuidado e o descuido com a natureza pontuam discussões que revelam problemas vivenciados por aqueles que são atores dessa realidade, seja no campo científico, político ou social. No caso específico de Ajuruteua no Nordeste Paraense, percebe-se que estas alterações da natureza foram significativas nas mudanças da paisagem natural da praia.

A mudança mais evidente ao longo da praia é a erosão ocasionada pelo avanço da maré, isso fica explicito na fala do entrevistado:

\footnotetext{
Nos últimos anos, mais precisamente na década de 90 para atual, tem sido grande a erosão marítima na praia de Ajuruteua e também na Vila dos Pescadores. Relatam os moradores mais antigos era uma praia muito grande, porém ao longo dos anos teve áreas de manguezais e de praias devastadas pela ação da maré, onde no final da década de 90, a maré avançou tanto que obrigou nossas famílias a mudarem pra outra área. (Pescador, informação verbal)
}

Segundo o entrevistado acima, o que há entre o passado e o presente da praia, nada mais é que uma significativa alteração no cenário paisagístico da praia, isso gerou problemas de ordem social e econômica, pois as famílias foram obrigadas a se deslocar para outras áreas. Ao afirmar que "era uma praia muito grande" demonstra que a erosão e avanço da maré comprometeram a natureza ao ponto de "afastar" as pessoas do espaço de convivência e 
trabalho. A força da maré destruiu casas e parte do comércio local da praia de Ajuruteua, isso pode ser ainda mais identificado na foto 3 :

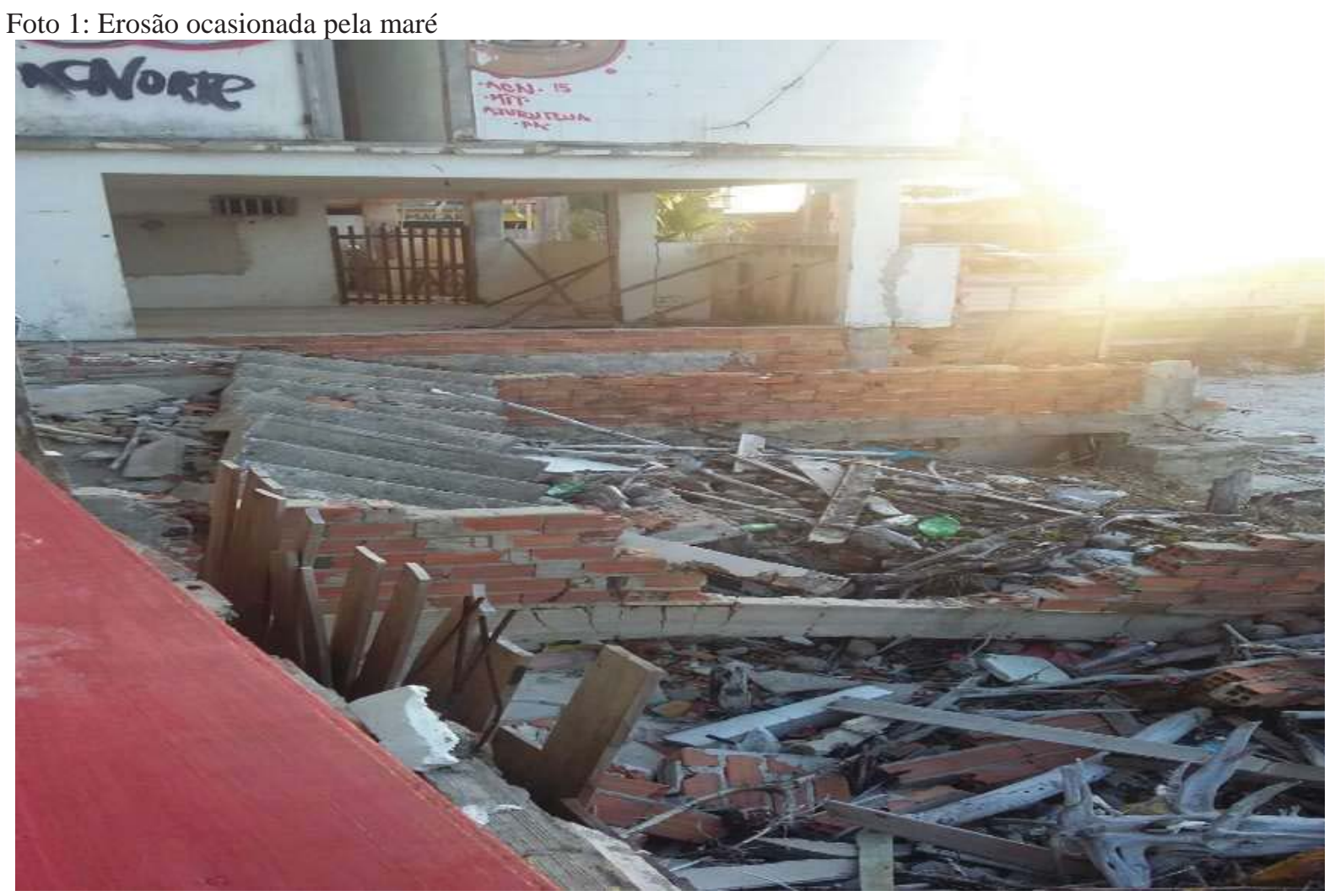

Fonte: GARVÃO, 2015

Esta mudança do cenário costeiro vem acompanhada por uma nova percepção da relação entre o homem e a natureza e, especificamente entre homem e o mar. "A erosão costeira é agora vista como parte de uma estrutura complexa do gerenciamento no qual muitas vezes as atividades do homem devem ser controladas e reguladas para permitir os caprichos do sistema natural costeiro" (RICKETTS, 1986, p. 219).

Entende-se que os processos erosivos são causados pela redução no aporte sedimentar provocada por diferentes fatores: retenção de sedimentos por obras de engenharia e inacabadas, modificações do perfil de equilíbrio a uma elevação do nível do mar ou a uma modificação do clima e altura de ondas.

$\mathrm{Na}$ Figura 4, pode ser observado que o reflexo do avanço da maré diante de construções de alvenaria (impróprias para o espaço costeiro) que não resistem a reação da natureza, torna-se visível a mistura dos resíduos sólidos ao lixo orgânico, ocasionando um acúmulo de materiais que poluem o visual da praia e descaracterizam a paisagem natural. 
Figura 2: Ocupação desordenada em Ajuruteua

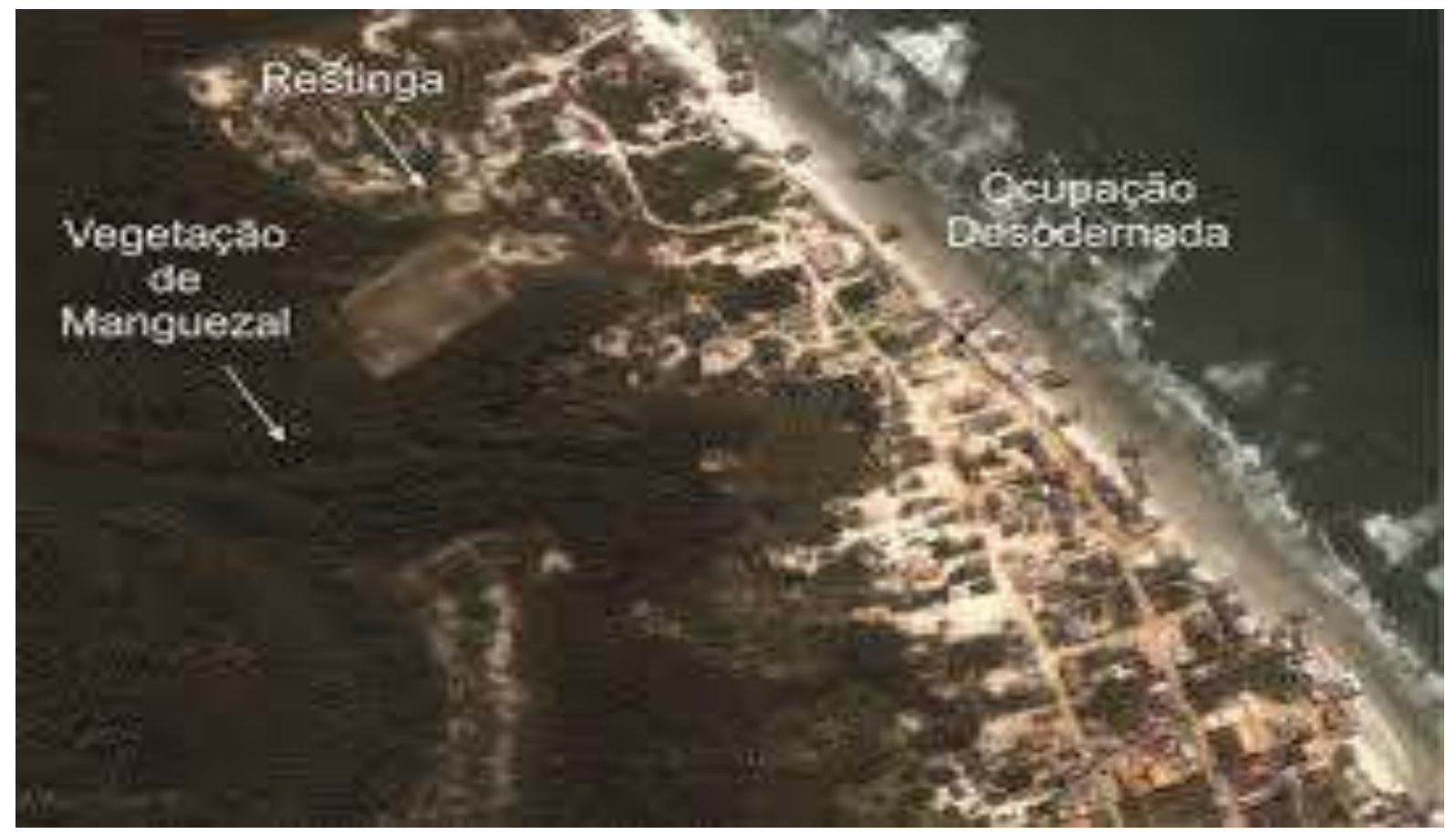

Fonte: Imagem de Satélite - Dep. de Geografia do Governo Federal.

As áreas na orla atualmente ocupadas que se encontram muito próximas à faixa de areia e com densidade de construção média ou alta possuem tendência a uma instabilidade local elevada ou muito elevada, portanto, são consideradas como áreas de risco potencial. A construção de bares, pousadas e pequenos comércios próximos a faixa de areia da praia de Ajuruteua vem promovendo uma fragilização do solo e consequente avanço da maré. A retirada de uma vegetação natural faz com a paisagem da praia sofra modificações significativas que podem se tornar irreversíveis e comprometa o futuro da população local. Fato este pode ser comprovado pela fala do entrevistado:

“Os pescadores mais antigos cederam espaços para a construção de pousadas e bares. Hoje a praia está diminuindo consideravelmente pela ação das ondas e marés, obrigando muitos a mudarem ou em algumas situações a perderem tudo." (Pescador, informação verbal).

Os intensos processos erosivos ocasionados pela dinâmica das marés na praia de Ajuruteua contribuem para a inserção de ocupações ilegais em áreas de preservação, pois a maioria dos estabelecimentos comerciais e residenciais são construídos em madeira e quando não destruídos por ação natural são facilmente transportados para lugares mais protegidos, ocupando assim dunas e manguezais, aumentando assim o índice de degradação ambiental costeiro. 
Para Ricketts (1986) até meados do século XX encarava-se o problema da erosão ${ }^{7}$ costeira como uma batalha entre o homem e o mar - para vencê-la o homem precisava controlar o mar e fixar a costa. Atualmente esta visão com soluções a partir de obras "duras" e rígidas vem sendo substituída por alternativas que incluem obras "leves" e flexíveis como a alimentação artificial de praias e dunas artificiais, a "re-vegetação", o recuo da urbanização, entre outras.

Na tentativa de conter a erosão por conta da maré é comum ver ao longo da praia de Ajuruteua a construção de muros de arrimo de forma muito artesanal, o uso de material pouco resistente como madeira bruta ou a construção de alvenarias colocadas para resistir os momentos do ano em que as águas estão "em grande maré”, como relatam os pescadores da Vila dos Pescadores.

Foto 3: Construções ao longo da faixa de areia

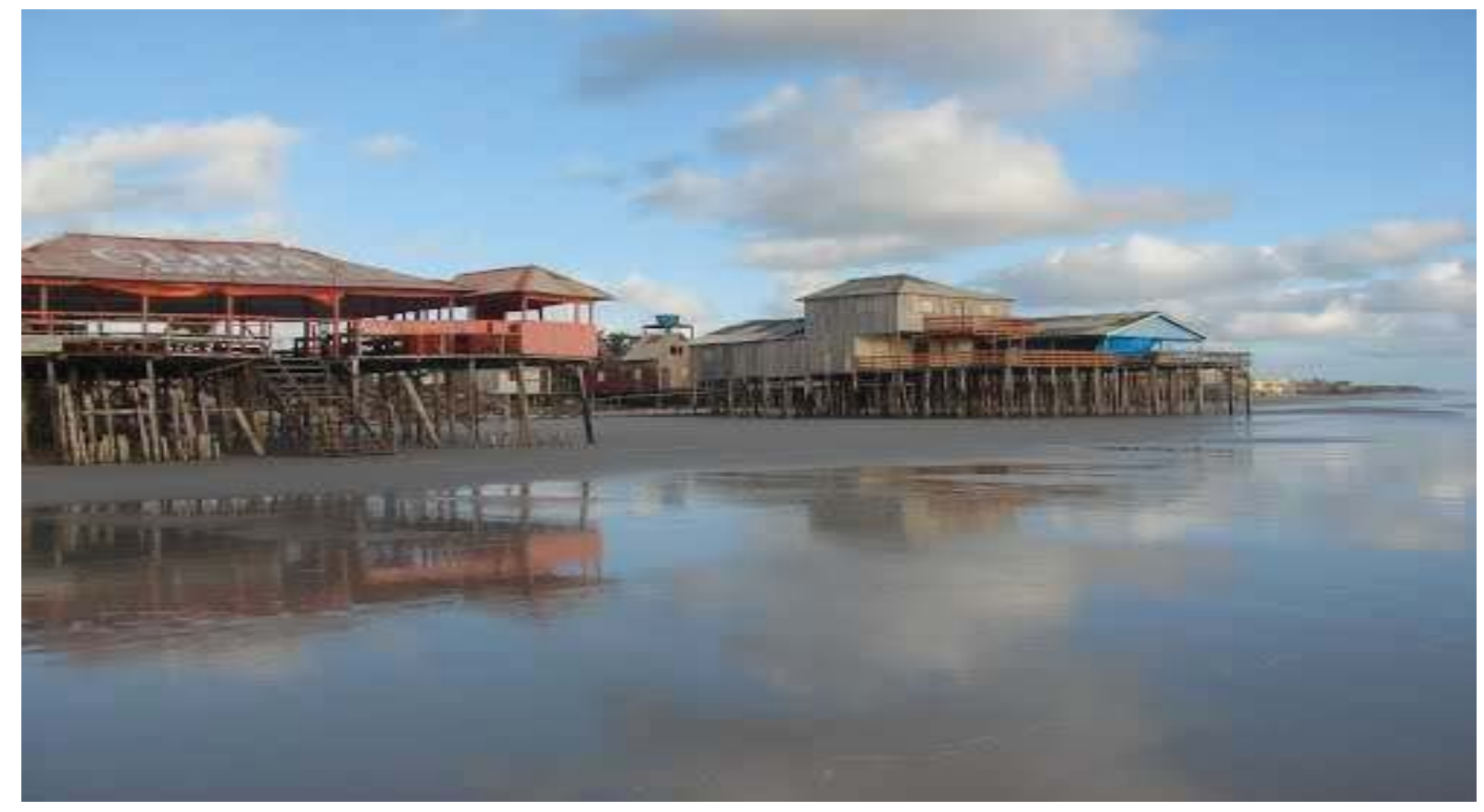

Fonte: GARVÃO, 2015

Essas moradias, em sua maioria, são feitas de madeira (Figura 6), com cobertura de palhas ou telhas. Ressalta-se que as casas em sua maioria são do tipo palafita para evitar as grandes marés, quando a água costuma invadir a "Vila dos Pescadores", onde ocorre intenso processo de erosão, ocasionado pela força das águas. Vale lembrar que essas residências não são de caráter permanente, em função desses constantes avanços da maré.

\footnotetext{
${ }^{7}$ Desgaste mecânico operado pelas águas correntes, pelo vento, pelo movimento das geleiras e pelos mares.
} 
A área litorânea de Ajuruteua é considerada como "de marinha", sendo assim, área próxima à praia, considera-se assim, uma pequena distância da linha mais alta da maré em direção a terra. Trata-se, portanto de terras devolutas, pertencentes à União, sendo de responsabilidade do Serviço de Proteção da União (SPU), tais áreas em princípio não podem ser compradas, há apenas o reconhecimento de ocupação. Talvez, por serem terras de domínio da União não são alvos de uma intensa especulação imobiliária.

Foto 4: Casa de Palafita, Vila dos Pescadores

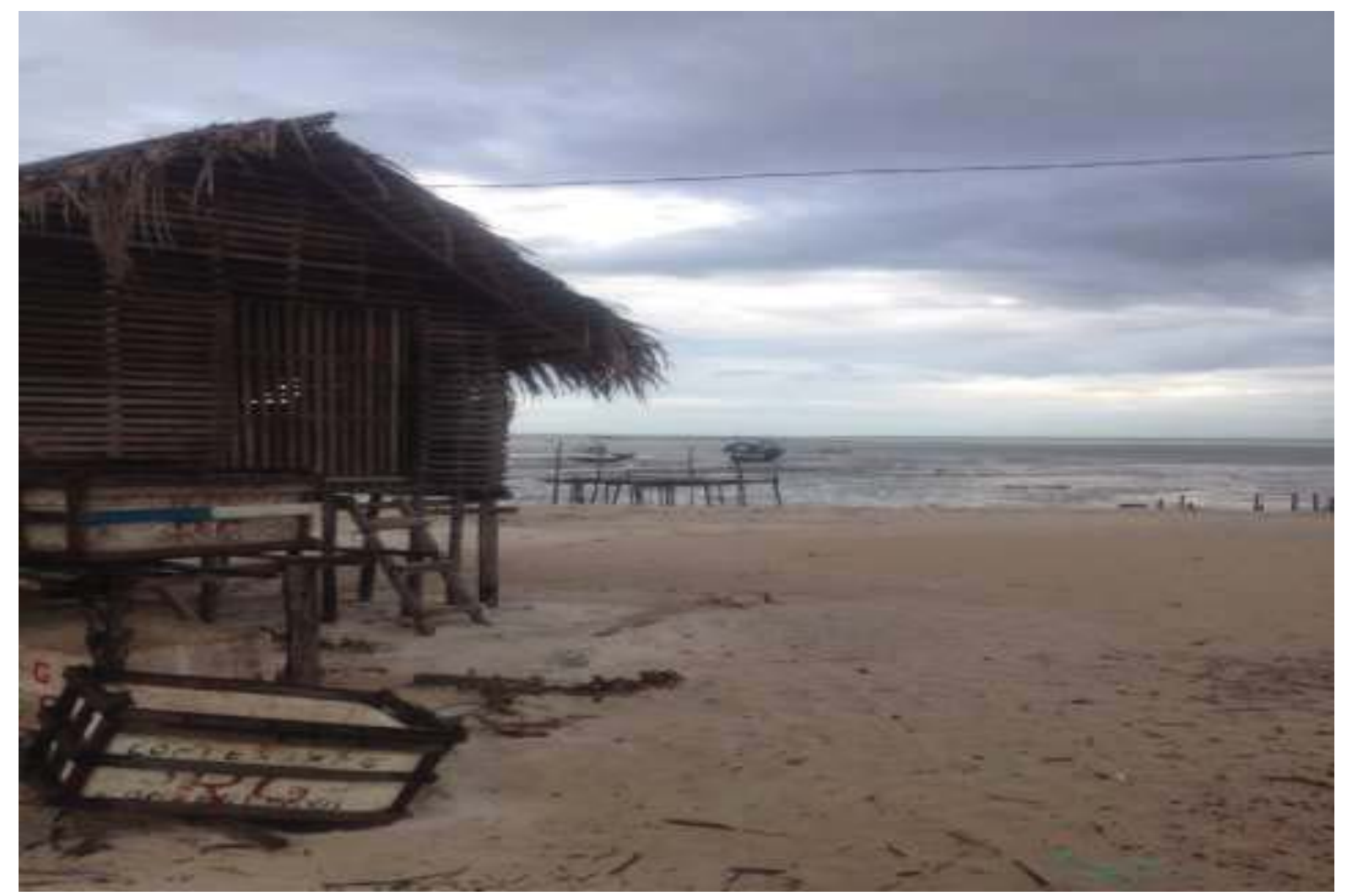

Fonte: GARVÃO R.F, 2015

Maneschy (1995) menciona que o turismo na região teve o efeito não só de valorizar os terrenos da praia de Ajuruteua, mas contribuiu com aumento da especulação imobiliária, com conflitos de uso dos solos, aumento da degradação ambiental, promovido principalmente, pela ocupação das dunas, do desmatamento do mangue, da deposição errônea de resíduos sólidos. A terra entrou em circuito da mercadoria e da apropriação privada, pois o contato com o urbano alterou o rol de aspirações de pescadores e filhos.

Neste contexto de produção e apropriação do espaço (tornando-o território), elencouse a praia de Ajuruteua, como espaço/território, sofrendo constantemente o processo de 
territorialização ${ }^{8}$, desterritorialização dos grupos que ali residem, surgindo a categoria de múltiplos territórios frente às múltiplas territorialidades. Estas diferentes territorialidades são sazonais criando usos diferenciados do território da praia, todos ligados a percepção e concepção de ambiente natural representado pela praia. Sendo assim, afirmamos que, "mais do que a desterritorialização desenraizadora, manifesta-se um processo de reterritorialização espacialmente descontínuo e extremamente complexo". (HAESBAERT, 1994, p. 214)

Maneschy (1995), entende que são facilmente introduzidas novas formas de apropriação da natureza, novas relações sociais de produção e novos estilos de consumo, que podem repercutir de várias maneiras sobre a comunidade, dificultando cada vez mais seu modo de vida e consequentemente acarretando inúmeros impactos no meio ao qual estão inseridos, uma vez que o avanço do litoral paraense ocorreu de maneira rápida e desordenada, causando sérias transformações ambientais, sociais e culturais nas populações locais, formadas principalmente por pescadores artesanais.

A territorialidade, além de mensurar uma dimensão estritamente política, diz respeito também às relações econômicas e culturais, pois está "intimamente ligada ao modo como as pessoas utilizam a terra, como elas próprias se organizam no espaço e como dão significado ao lugar". Sack (1986) afirma:

\footnotetext{
A territorialidade, como um componente do poder, não é apenas um meio para criar e manter a ordem, mas é uma estratégia para criar e manter grande parte do contexto geográfico através do qual nós experimentamos o mundo e o dotamos de significado. (SACK, 1986, p.219).
}

Outro ponto importante a ser mencionado é o acúmulo de lixo orgânico nos quintais das casas, principalmente as casas de veranistas. Segundo os pescadores, esse lixo composto por folhas secas, frutos do mangue, "paliteiras" ou "canetas"9 do mangue e pedaços de árvores que a força do mar derruba em encostas dos estuários e arremessa para as proximidades das casas serve como barreira natural para o avanço da maré.

\footnotetext{
${ }^{8}$ Segundo HAESBAERT (1994) A territorialidade, além de incorporar uma dimensão estritamente política, diz respeito também às relações econômicas e culturais, pois está "intimamente ligada ao modo como as pessoas utilizam a terra, como elas próprias se organizam no espaço e como elas dão significado ao lugar”

${ }^{9}$ Nome vulgar dado à vegetação do mangue pelos pescadores da região, devido seu formato alongado de proporções aproximadas de uma caneta. Nome científico: Rhizophora mangle
} 


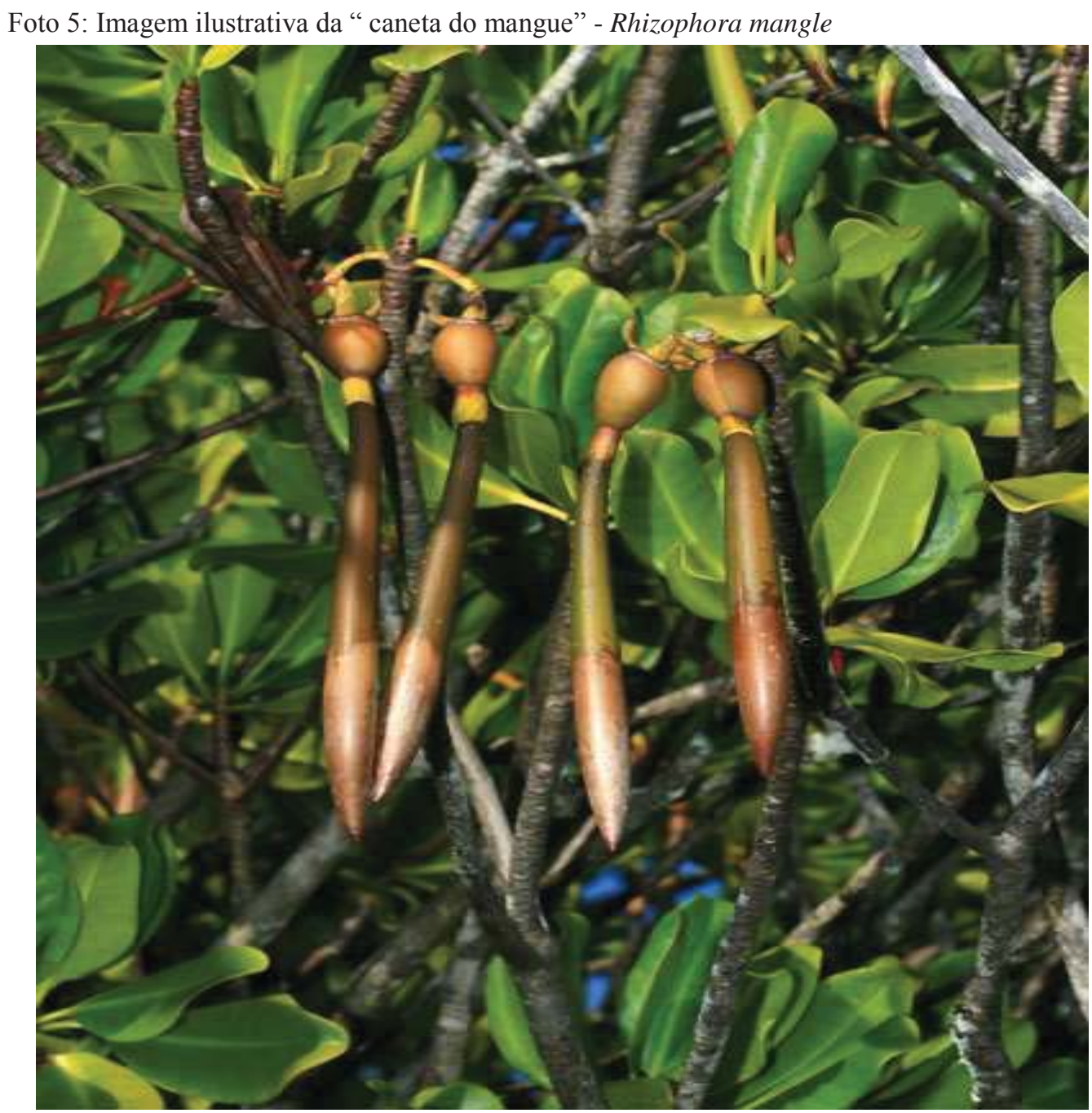

Fonte: http://wildlifeofhawaii.com

Contudo, com a frequência de banhistas e turistas esse lixo orgânico se mistura ao lixo composto por resíduos sólidos como copos de plástico, embalagens de picolés, pequenos brinquedos, até tecidos e roupas, entre outros, formando ao longo da praia e dos quintais das casas um acúmulo de material de diferente origem, sem definição daquilo que seja importante para a preservação da natureza. 
Foto 6: lixo acumulado na orla de Ajuruteua

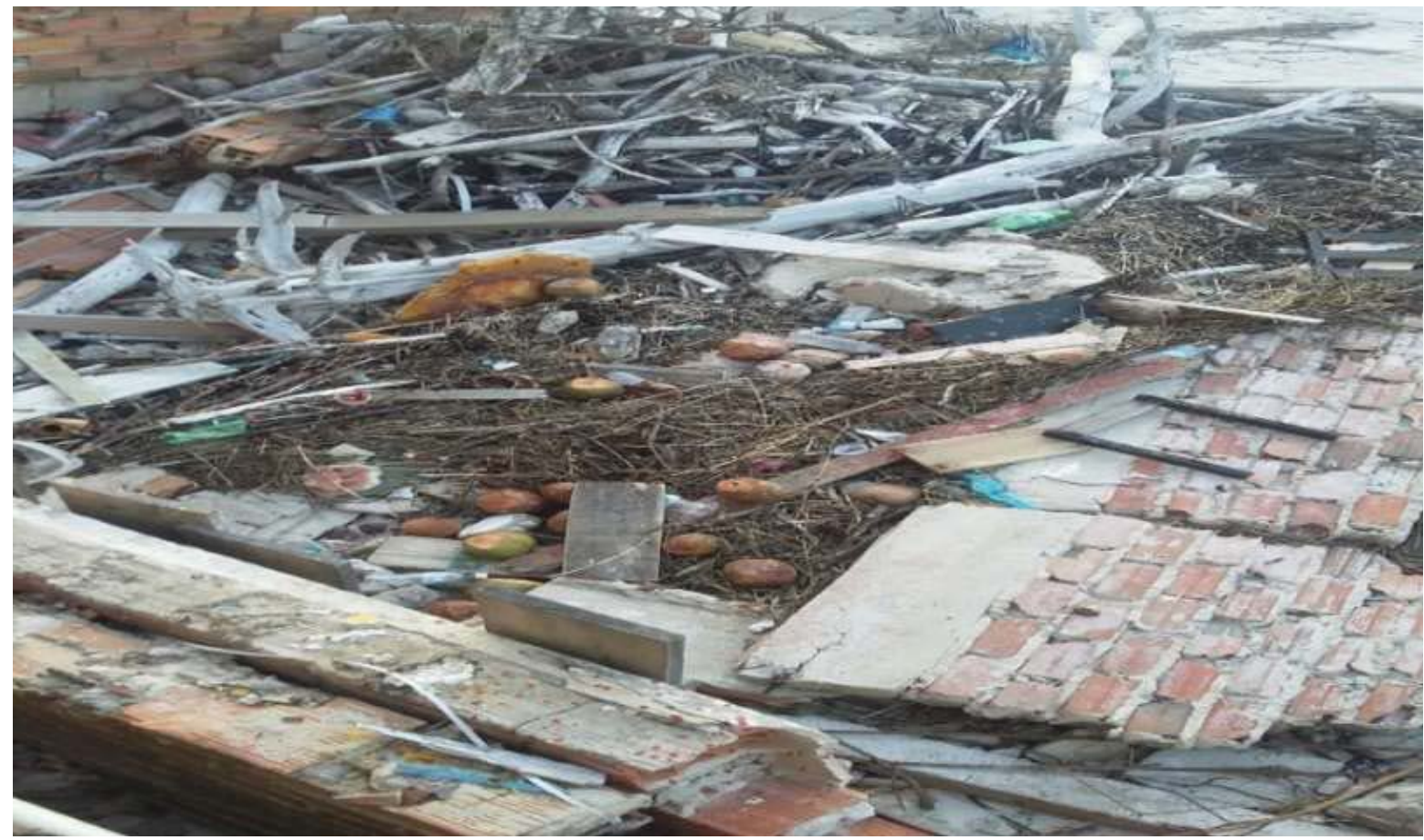

Fonte: GARVÃO,2015

Percebe-se uma falta de educação ambiental direcionada aos pescadores e moradores da Vila para que os mesmos possam ter consciência de que o lixo trazido pela maré, não é o mesmo lixo domiciliar. Observa-se a ausência de lixeiras ao longo da orla, motivo pelo qual este lixo é depositado nas ruas, na faixa extensa de areia e nas áreas do mangue existente no ecossistema local.

Tem muito turista e até morador daqui que joga o lixo no chão, mas eu não... de vez em quando eu junto os sacos plásticos e uso pra colocar camarão pra vender lá na praia. (Pescador,informação verbal).

Diante desta situação, a administração pública do município de Bragança, na responsabilidade da Secretaria Municipal de Meio Ambiente, tenta amenizar o problema realizando a coleta desses resíduos, por meio de pequenos tratores, fazem a retirada de boa parte desse "lixo", mas não de forma seletiva, isso faz com que exista a eliminação também de barreiras naturais para o avanço da maré, como observado na fala a seguir:

\footnotetext{
"Tá vendo aquele lixo ali? Aquele lixo todo a água tráz, ai o vento joga areia né...ai ele vai, vai aterrando né...que lá na outra praia eles... a prefeitura mandava aqueles tratorzinhos tirar aquele lixo, afim de não furar os "pé" dos turistas né...então aquilo ali segura a praia, ali eles tiravam o lixo permanente, então a água não tinha como "vim', como eles tiraram o lixo, a água vem agora..." (Pescador, informação verbal).
} 
Como algumas residências foram adquiridas por turistas ao longo da praia, e em sua maioria moradores de Belém, em épocas de veraneio como Julho, Janeiro e em longos feriados, é muito comum a queima de lixo acumulado nas casas ao longo dos outros meses. Essa prática também acaba com a barreira natural da maré, e em muitos casos é alertada pelos pescadores, como pode-se observar na fala abaixo:

\footnotetext{
"Tem muita casa de veraneio, de turista que passa as férias aqui, passa feriado, aí eles queimam, eles fazem queimada, aí a gente vai lá e fala pra eles, pra não queimar... queimar o lixo da praia né... o lixo que a água tráz, ai ficam de noite ai batendo violão, aí tocam fogo no lixo né... aí a gente vai lá e fala pra eles ou apaga. Tem muitos que tem consciência, outros não tem." (Pescador, informação verbal).
}

Para uma eficácia de toda limpeza ao longo da praia, este lixo deverá ser submetido a uma triagem separando o lixo orgânico ao inorgânico, evitando assim, a destruição da barreira natural da maré, e o retorno de todo este plástico ao mar, comprometendo a saúde da fauna marinha.

Verifica-se que o lixo é um problema inerente à existência humana. Cada pessoa gera uma enorme quantidade de resíduos que nos cercam nos diferentes lugares. Na região litorânea também não seria diferente, há presença de resíduos que podem custar caro as comunidades costeiras, seja pela perda do potencial estético e turístico e da qualidade da água das praias ou pelos custos despendidos pela limpeza pública e até mesmo pelas doenças associadas ao lixo. O lixo na costa brasileira resulta em vários efeitos nocivos na biota marinha, e traz sérios prejuízos ao turismo, e a saúde dos banhistas.

Para Nash (1992) a atividade pesqueira, o lixo marinho traz sérias consequências negativas. Os prejuízos podem ser nos mais variados métodos de pesca, direta ou indiretamente. Entre os impactos diretos estão a presença de resíduos flutuantes e a incidência de lixo em redes e anzóis de pesca, que diminuem a produção ou impedem a atividade.

Quanto aos problemas indiretos os resíduos no ambiente marinho chegam a danificar embarcações, aumentam os gastos com manutenção e diminuem o tempo da pesca. De fato, dentre os vários atores da degradação de recursos naturais, destaca-se as derrubadas de árvores do mangue para fabricação de carvão:

"Podemos até deixar de tirar as árvores do mangue pra fazer carvão...mas não tem outros tipos de árvores aqui perto, porque é desse jeito que fazemos lenha pra colocar no fogão, pra mulher cozinhar." (Pescador,informação verbal).

Segundo Carvalho (2000) ao longo dos tempos, os mangues foram ficando cada vez mais degradados, principalmente, considerando os de extração de árvores de mangue, os 
troncos são utilizados na produção de lenha e carvão vegetal para o uso em padarias e olarias da região, bem como a armadilha de currais na pesca.

Fernandes (2003) acredita que todo processo de degradação dos manguezais afeta diretamente os sistemas aquáticos adjacentes pois necessitam diretamente da matéria orgânica exportados pelos manguezais. Isto acontece via empobrecimento das águas ao redor dos manguezais, afetando diretamente a reprodução dos peixes, crustáceos e moluscos que se reproduzem nos lagos, furos e rios dos estuários.

Outro acontecimento que modificou as rotineiras relações de trabalho entre os pescadores e a paisagem natural da praia foi a construção da rodovia PA 458 (Estrada Bragança- Ajuruteua) e tais mudanças podem ser percebidas tanto nas interações sociais quanto ao meio natural, que intensificaram a captação de caranguejos e o turismo local, pela facilidade de acesso à praia, afirmativa observada na fala abaixo:

Olha mano, quando eles fizeram essa estrada pra cá foi o ponto crucial, aquele ponto certo... a natureza deu o troco, da outra praia pra cá... Ajuruteua era grande, bonita aí depois que fizeram a estrada, estabilizou a estrada, começo vir gente, acabou muita coisa... (Pescador, informação verbal).

É considerável expor como ponto de reflexão que a estrada Bragança-Ajuruteua ( Foto 9) , sobre muitas maneiras, acabou por interferir diretamente nas dinâmicas de trabalho daqueles de vivem em atividade de extração do pescado, com a expansão da rodovia, os moradores passaram a receber atravessadores, cujo interesse é a compra do pescado. Sendo assim, houve a dinamização da pesca, devido a possibilidade de vender o pescado, sem a necessidade de ir a Bragança por via marítima. 
Foto 7: Rodovia PA 458 (Bragança-Ajuruteua)

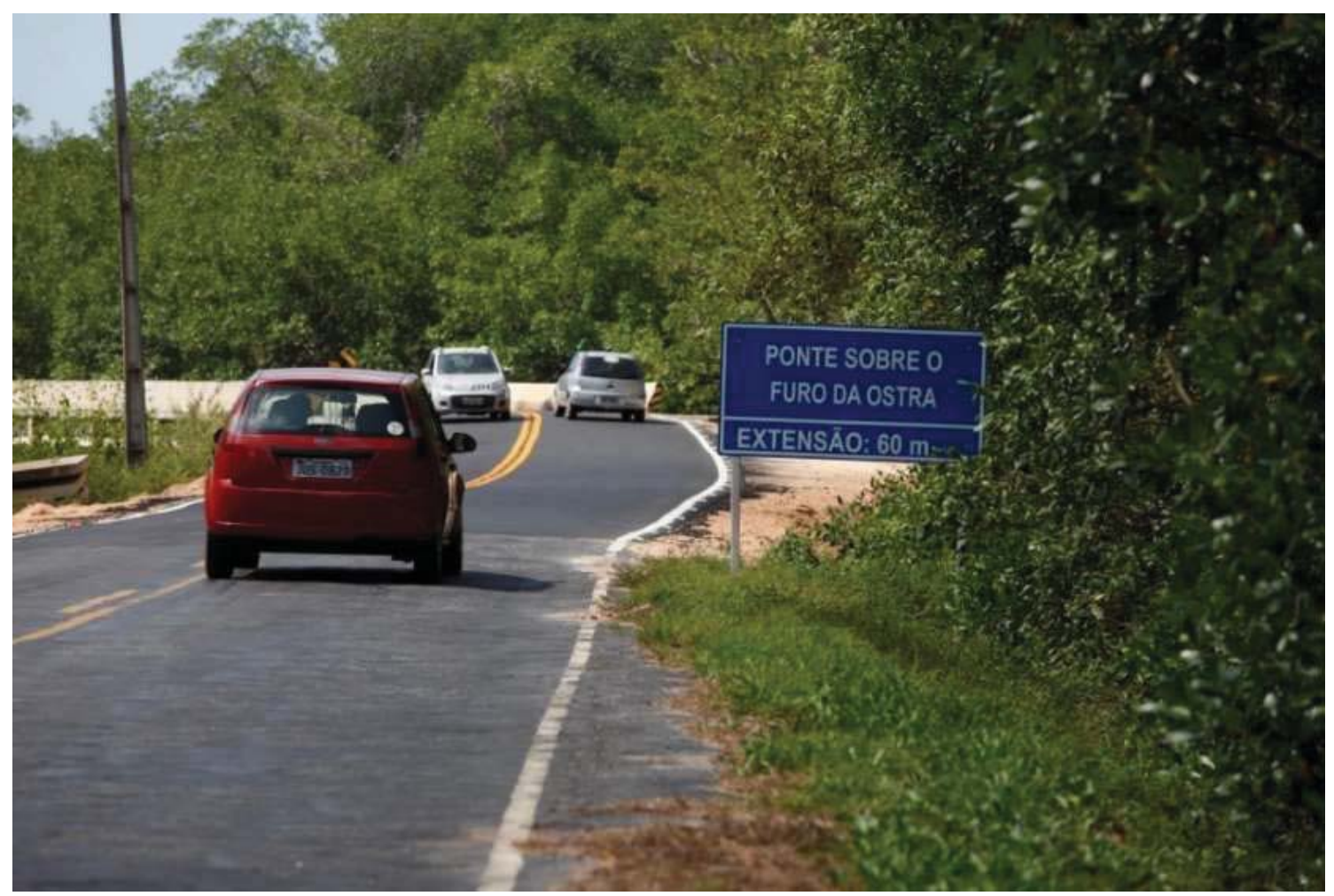

Fonte: Agência Pará,2015

Observa-se uma preocupação com o meio ambiente aliado à construção da rodovia PA-458 por parte da população local, principalmente dos jovens e crianças, sensibilizando-os em relação ao meio em que vivem. Este fato ocorre principalmente os que estão estudando e recebem uma orientação, mesmo que simplória, nas escolas.

"Eu sempre observo o que está acontecendo aqui na vila, tem o problema da estrada né? Acabou tudo ao redor, até tapou um furo lá na frente, na escola do meu filho estão fazendo um trabalho de meio ambiente, e as crianças gostam." (Pescador,informação verbal).

Segundo Souza Filho (1995) ao longo dessa estrada, observa-se áreas cuja vegetação do mangue já foi completamente removida, estando o solo lamoso, expondo a incidência de raios solares que provocam a formação de gretas de contração, além de desencadear modificações das condições físico-químicas do solo, que geram certamente prejuízos a atividade biológica.

Souza Filho (1995) ainda relata que outro problema ocasionado com a construção da rodovia PA 458 está relacionado à desestruturação de parte da rede de drenagem, uma vez que diversos canais da maré, responsáveis pela circulação dos nutrientes no ambiente do manguezal, foram cortados pela estrada e que em alguns trechos funciona como barragem ao 
fluxo de marés, gerando enormes áreas com água represada. Tal modificação tem gerado novas condições ambientais que alteram o funcionamento do ecossistema de manguezal, desde o processo de sedimentação ${ }^{10}$, condições físico-quimicas das águas até a fauna e flora vivente, conforme foto abaixo

Foto 8: Degradação do mangue - Ajuruteua

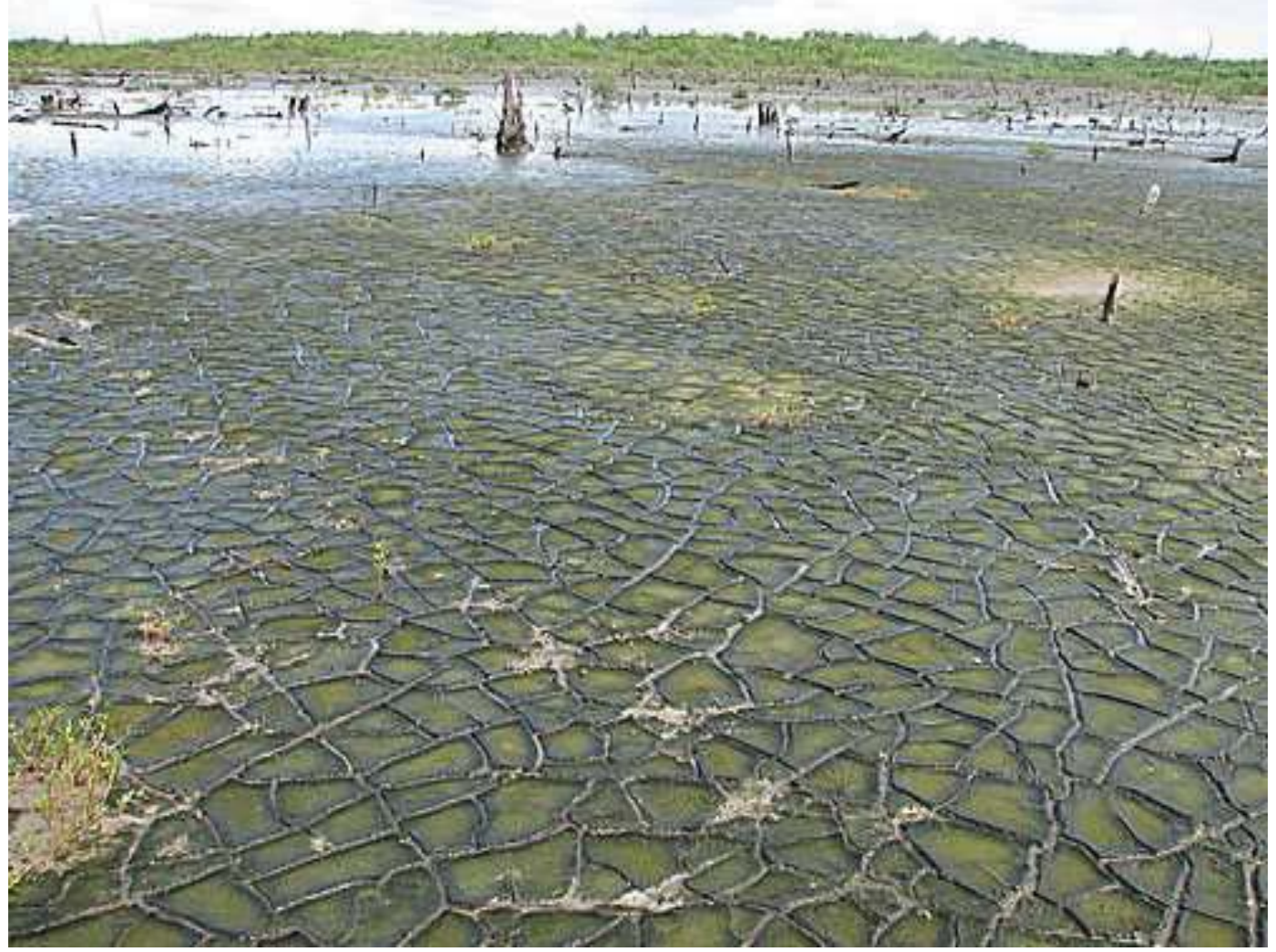

Fonte: CASTRO, 2007

Como resultado do aumento da degradação ambiental exercida sobre a natureza, tanto em Bragança como na costa de Ajuruteua, os moradores da Vila dos Pescadores apontam uma diminuição do tamanho das espécies do pescado e na quantidade de peixes capturados. Esses depoimentos relatam a degradação ambiental da fauna em larga escala, o que vem preocupando os pescadores até mesmo para o sustento familiar:

\footnotetext{
"Quando a gente chegava antes aqui, com os peixes, era um peixe grande que alimentava a família, hoje tem que pegar mais de seis pra todo mundo comer." (Pescador, Informação verbal).

"Se não for feito algo logo, por parte "das autoridade", os peixes vão acabar logo, já não tá dando pra todo mundo que mora aqui.” (Pescador,Informação verbal).
}

\footnotetext{
${ }^{10}$ Processo pelo qual substâncias minerais ou rochosas, ou de origem orgânica se depositam e se consolidam de forma firme em ambiente aquoso.
} 
Esses depoimentos nos permitem compreender a degradação ambiental e diminuição dos recursos pesqueiros, assim, é necessário capturar maior número de peixes de menor tamanho, para dispor da mesma quantidade. Este artifício é usado para contornar a questão da quantidade de recurso natural explorando espécies ainda não adultas da população de peixes podendo levar a uma eventual extinção dos estoques de determinadas espécies.

Exemplificando a alteração da fauna local, algumas espécies do pescado são relatadas por pescadores como críticas em termos de abundância na atualidade, ao contrário dos anos 80. Isso fica bem explícito na fala abaixo:

"Teve muito peixe que desapareceu, o "cação espardate", aquele que tinha aquela serra. Hoje... hoje se a pessoa disser: Poxa... um pedaço de "espardate" for remédio pra curar essa sua doença, o cara vai morrer... não existe mais. E há trinta anos dava demais, meu filho tem 32 anos e quase que ele não conhece o "espardate". Poxa... e dava tanto..." (Pescador,Informação verbal).

Para melhor visualização e entendimento, segue abaixo imagem ilustrativa da espécie "Xiphias Gladius", popularmente chamado como Cação Espadarte:

Foto 9: Cação Espadarte

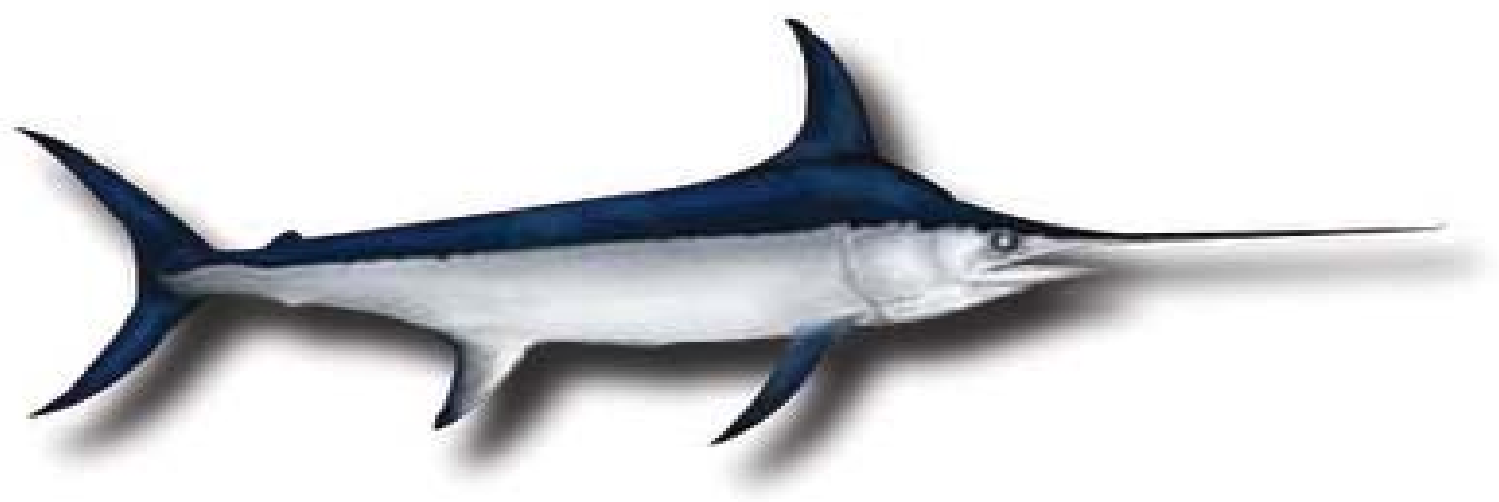

Fonte: peska.com.br

O surgimento de grandes empresas de pesca, aliado à grande exportação do pescado favoreceu também a diminuição de espécies de peixes:

"Entrou grandes empresas de pesca aí né? Acabou né? Você atravessa aqui até ele mangal, tranquilamente... antigamente você só podia ir de canoa, porque podia ser atacado né, não tinha rede, não tinha empresa de pesca assim, não tinha nada." (Pescador, informação verbal).

Essa situação a curto prazo leva a um aumento no volume de produção em decorrência da elevação do esforço de pesca motivado inclusive pela entrada, a cada ano, de um maior número de pessoas e industrias pesqueiras na atividade. A longo prazo, em decorrência dos 
recursos pesqueiros serem de uso comum, a produção por embarcação tende a reduzir gradativamente como fruto da pressão sobre a reprodução dos estoques pesqueiros. (SANTOS, 2005)

Outro fator mencionado pelos pescadores é a presença de pescadores oriundos de outros locais, provenientes em sua maioria do Maranhão e Ceará, que são grandes responsáveis também pela diminuição dos estoques pesqueiros da região. Este fato é vivenciado pelos pescadores com o aparecimento de diversos barcos com redes bem maiores que exploram o litoral da praia de Ajuruteua. Isso pode ser observado nas falas e na figura abaixo:

\begin{abstract}
"Esses barcos que chegam aqui tem mais equipamento que nós daqui, eles tem mais dinheiro e usam redes grandes, pesca peixe de tudo que é tamanho, ficam com os que prestam e jogam o restante no mar, e ninguém faz nada." (pescador, Informação verbal).

"Os barcos de fora são uma praga, vem aqui buscar nosso camarão e lagosta, acabam com tudo e vão embora, já acabaram com tudo na terra deles e agora vem pra cá." (Pescador, Informação verbal).
\end{abstract}

Foto 10: Grandes embarcações

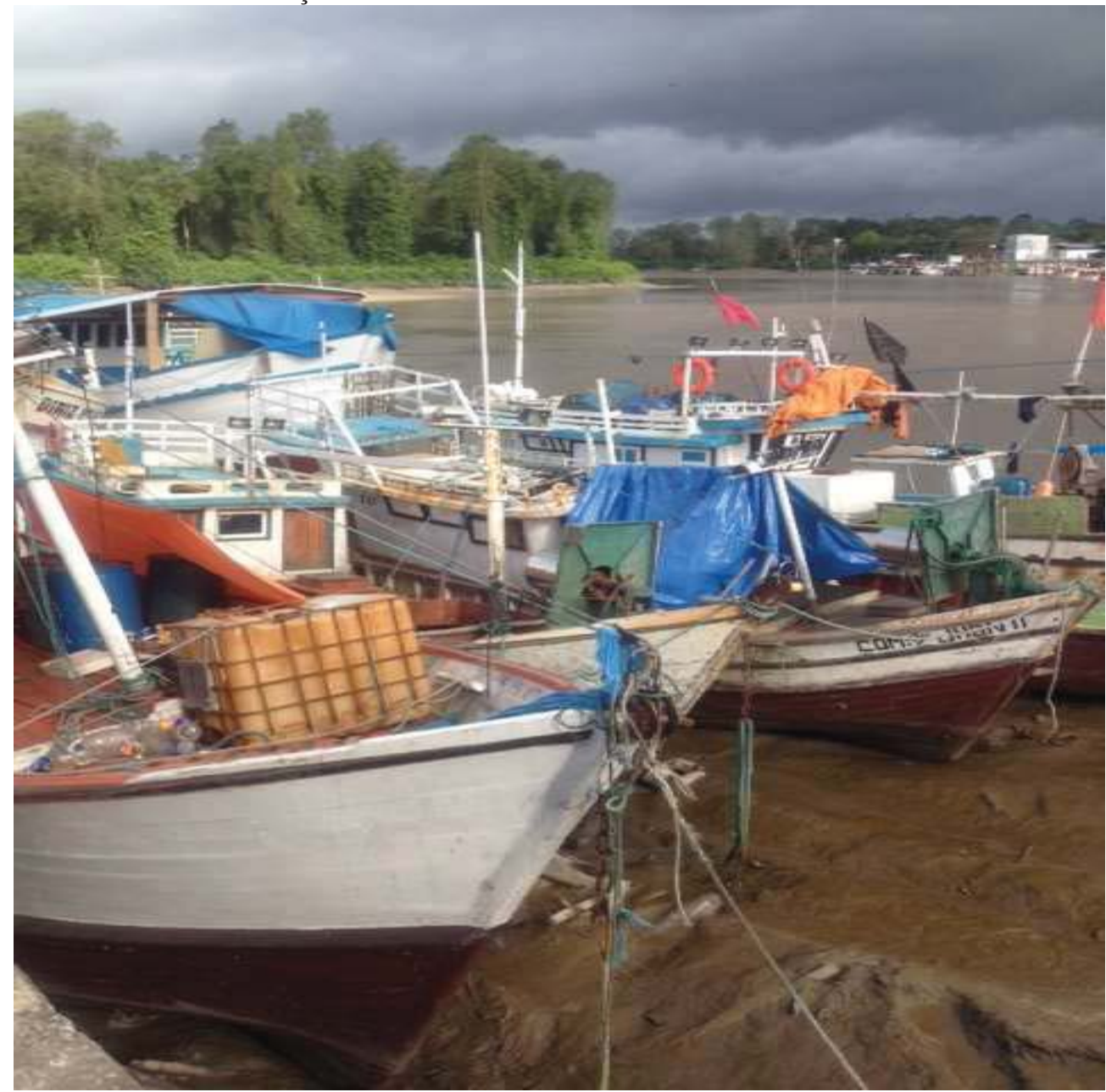

Fonte: GARVÃO, 2015 
Goes (1979) menciona que os impactos ambientais, tanto diretos quanto indiretos, existentes nos vários ecossistemas ao longo da zona costeira são principalmente de origem antrópica, ou seja, provocados pelo homem. Toda essa problemática prejudica a preservação dos ecossistemas costeiros, demonstrando a falta de consciência ambiental da maioria dos usuários, além da ausência de políticas administrativas adequadas e ecologicamente corretas. Consequentemente acarretam modificações no hábito de vida das populações tradicionais, influenciando diretamente na estrutura das populações locais, incluindo alterações nos aspectos do modo de vida regional e com relação aos aspectos socioeconômicos.

A pressão sobre os estoques de recursos naturais causadas pelo uso e exploração sem controle na praia de Ajuruteua é avaliada por moradores da Vila e pescadores como desproporcional, ou seja, a quantidade extraída não é equivalente à demanda da região.

\footnotetext{
“A minha família só cresce, os filhos cresceram e alguns já tem filhos, então se pega mais peixe pra sustentar as criança.” (Pescador, Informação verbal).
}

Percebe-se que os pescadores não sabem se o maior grau de exploração dos recursos naturais é considerado como ameaça à sobrevivência e posteriormente às gerações futuras, mas o impacto ambiental já é notório.

Essas alterações na vida regional em Ajuruteua são intensificadas nos meses de verão intenso, na medida que ambulantes de outras regiões retiram árvores nas proximidades da praia para a construção de pequenas barracas para vendas de iguarias e produtos industrializados, como bebidas e laticínios em geral, como ilustrado na fala abaixo:

\footnotetext{
"Muita gente de outras regiões que vem no verão pra cá e toram as arvores para construir barraca pra vender coisas aqui na praia. Acabou o verão, vão embora e no outro ano vem tudo de novo, aí vem mais gente e faz tudo de novo." (Pescador,Informação verbal).
}

Sem dúvida, a introdução do turismo na região tem acarretado mudanças em vários aspectos do modo de vida tradicional da população local, o processo de ocupação da praia está em avançado crescimento. No verão, observa-se a chegada de novos empreendimentos turísticos e do movimento de turistas no local, sem qualquer planejamento e desconhecendo e desprezando qualquer legislação ambiental que possa existir, em detrimento do uso e exploração dos recursos naturais na praia de Ajuruteua.

Por um lado, Maneschy (1995) contextualiza a relação de dependência financeira dos moradores frente aos fluxos turísticos na região, suas limitações estruturais e as mudanças recentes na manutenção das formais mais tradicionais de organização social. 
Em Ajuruteua há um estacionamento de ônibus em área de mangue, nas proximidades da praia. Ao longo dos anos, segundo pescadores o local vai ganhando proporções maiores, adentrando ao mangue. Contudo, percebe-se uma inerência dos pescadores sobre o perigo que esta ação causa no ecossistema local:

\footnotetext{
“Ali é o estacionamento, é preciso um local pra colocar os ônibus dos turista que traz esse monte de gente." (Pescador, Informação verbal)

“Já faz um tempo que isso acontece, todo ano é isso... só aumenta, mas se não colocar os ônibus ali, aonde vai colocar?’( Pescador, Informação verbal)
}

O tipo de turismo que atualmente ocorre na praia de Ajuruteua, não contribui para a aproximação dos visitantes da paisagem litorânea e para uma compreensão do cotidiano dos moradores.

\section{CONSIDERAÇÕES FINAIS}

Os espaços litorâneos têm sido alterados consideravelmente em função de múltiplos impactos ambientais provenientes de atividades que perduram ao longo dos anos, exemplificando: uso inadequado do solo, desmatamento do mangue, lançamento de resíduos domésticos ao mar, e como consequência observa-se uma desestruturação do ecossistema marítimo.

Todo este processo de desestruturação do ecossistema elucida as percepções ambientais a cada ser humano, e imprime uma valorização da paisagem natural e da cultura local, com a substituição ou criação de novos hábitos e comportamentos em relação a apropriação na natureza.

A existência da sociedade insere reproduções de atividades que impactam o meio ambiente de maneira direta, traçando a reciprocidade entre o humano e a natureza, ocasionando sérios desgastes na paisagem costeira, através desse dinamismo, que sofrem mutações no meio em que são inseridos.

No caso da praia de Ajuruteua, não seria diferente. O cenário atual encontrado na praia é reflexo de uma significativa mudança na paisagem natural através da intervenção do homem, a ocupação desordenada do seu espaço, ausência de políticas públicas eficientes ocasionando um ciclo insustentável.

Com base na hipótese traçada na presente pesquisa, teve-se a preocupação em investigar os projetos ambientais que buscam um traço sustentável, afim de amenizar os 
impactos ambientais causados pela ocupação desordenada de moradores da Vila dos Pescadores, o turismo intenso depois da construção da BR PA-485, que passados mais de 20 anos de construção da rodovia, a praia de Ajuruteua vem sofrendo transformações sociais, culturais e econômicas, e principalmente ambientais.

Notou-se que as visões dos pescadores sobre a estrada parecem ser indecisas, pois se por um lado reconhecem a destruição do mangue, por outro lado destacam benefícios econômicos que a estrada Bragança-Ajuruteua ajudou a elevar.

Entre os impactos ambientais decorrentes da construção da PA-458 o mais visível é o impedimento do encontro das águas provenientes do Rio Caeté, onde a estrada que corta o manguezal serve de barragem para a transição das águas dos rios e também dos nutrientes necessários para a manutenção da vegetação de mangue do lado em que se encontra o rio Taperaçu. Houve o soterramento de igarapés e de canais, que impediram também a troca de águas dos campos salinos quando há a maré alta.

Em relação à prática do turismo local, alguns problemas se agravam pelo descaso das autoridades locais, que incentivam o turismo na região do Salgado, sem antes promover um planejamento sobre uso e ocupação do solo.

Nota-se que turistas e moradores da Vila dos Pescadores, não se consideram prejudicados pela ação turística da região. O pescador da Vila julga o turista de acordo com seu comportamento. Os turistas desconhecem os pescadores limitando os relacionamentos à comercialização de produtos e uso de serviços que lhes são oferecidos.

Dentro dos objetivos estava a investigação através de entrevista aos pescadores, as alterações na paisagem natural da praia. Observou-se entre elas, a diminuição do pescado ao longo dos anos, isso se dá provavelmente a pesca comercial em larga escala, inclusive com a chegada há cerca de quinze anos, de uma frota de pescadores provenientes da região nordestina brasileira, com tecnologias mais avançadas, como a rede de arrasto, aos pescadores de Ajuruteua, que utilizam da pesca essencialmente artesanal.

Foi possível verificar um grande fluxo de pessoas atraídas pela praia em períodos de veraneio, contudo há uma mudança no comportamento dos moradores da região em função disso, aproveitando novas oportunidades de renda e acarretando uma pressão maior sobre o meio. Todo esse reflexo que o turismo de massa provoca no cotidiano dos moradores provoca alterações ambientais como o acúmulo de lixo nos quintais das casas e encostas da praia.

Quanto ao lixo, os moradores e pescadores ainda não distinguem lixo orgânico e resíduos sólidos. O acúmulo de lixo é retirado pelo governo municipal, na medida em que 
realiza a coleta pública, mas contra essa atividade há a retirada da barreira natural contra o avanço na maré.

Observou-se em relação a este aspecto, um comportamento de inerência dos pescadores com relação ao local de moradia e trabalho e ameaças naturais decorrentes do acúmulo de lixo, indiferente de sua origem (domiciliar ou natural).

Como dito anteriormente e observado pelos pescadores, há um processo de erosão em toda Orla de Ajuruteua, decorrente do avanço da maré. Isso se dá pela ausência de uma fiscalização municipal eficaz à ocupação desordenada e adequação aos parâmetros exigidos no projeto Orla, contudo Bragança aderiu ao projeto em meados de 2014, e o mesmo está em vias de planejamento.

Visivelmente há um desmatamento do mangue nas proximidades da praia de Ajuruteua, isso se dá em função da extração de madeira para construção e reformas das casas de palafitas, estas de turistas ou moradores e para o estacionamento de veículos automotores nos meses de veraneio, contudo nada efetivamente é feito por parte dos pescadores para deter tal desmatamento e desequilíbrio do ecossistema do mangue.

\section{REFERÊNCIAS}

ANTUNES, P. B.. Dano ambiental: uma abordagem conceitual. Rio de Janeiro: Lúmen Júris, 2000.

BABBIE, E.R. Survey research methods. Belmont, Calif: Wadsworth, 2001.

BELFIORE, E. 'Economic Impacts: Inconclusive Evidence', Arts Professional, Issue 43, 2003

BRAGANÇA,P. (2015) Bragança ordena espaços litorâneos, disponível em http://www.braganca.pa.gov.br, acessado em 26/11/2015.

CABRAL,N.W. O turismo como agente de formação e transformação sócio-economica no nordeste do Pará: caso de Ajuruteua. Depto de Turismo, UFPA, 1997.

CAMPOS. I. D.; GAMA, A. T.. História de vida de homem da natureza. In : História Agora: Revista História do tempo Presente. São Paulo: Editora da Universidade de São Paulo, 2010 .

CAMPOS. I. D. História e natureza: memórias, sobrevivências, famílias e relações de poder no manguezal. (Bragança-PA, 1980 a 1990). Revista Margens, Campus de Abaetetuba da Universidade Federal do Pará, UFPA, 2010.

CAPRA, F. Falando a linguagem da natureza: Princípios da sustentabilidade. História do Pará. Belém: UFPA, 2006. 
CARVALHO, E. A. Impactos ambientais na zona costeira: o caso da estrada BragançaAjuruteua, Estado do Pará. Universidade de São Paulo, Dissertação de mestrado em ciências do ambiente, 2000.

COSTA. F. de A. Questão agrária e macropolíticas na Amazônia: Novos momentos grandes desafios. Revista do centro de estudos avançados, n. 53, jan-mar., São Paulo: USP, 2005.

DANTAS, E. W. C. Maritimidade nos trópicos: por uma geografia do litoral. Fortaleza: Edições UFC, 2009.

ESPIRITO SANTO, R,V. Caracterização da atividade de desembarque de frota pesqueira artesanal de pequena escala na região estuarina do Rio Caeté, Bragança.PA, 2002.

FERNANDES, M. E. B. F. Produção Primária: serapilheira. In: FERNANDES, M. E. B. F (ORG). Os manguezais da costa norte brasileira. Maranhão: Fundação Rio Bacanga, 2003.

FERRARA, L. Olhar Periféric: linguagem, percepção ambiental. Ed. São Paulo, USP, 1999.

FRANÇA. M C.; CAMPOS, O. T. L.; LEAL, L. H. Novas Oportunidades na Aquicultura: o Cultivo de Ostras na Zona Costeira do Estado Pará. Engrenagem: Revista do Instituto Federal de Educação, Ciência e Tecnologia do Pará - Campus Belém, Ano I - No 1 Belém/PA, Junho/2011.

FURTADO, L.G. Curralistas e Rendeiros de Marudá, pescadores do litoral do Pará. Museu Emílio Goeldi, São Paulo, USP, 1980.

GLASER, M. FURTADO; NASCIMENTO, L.G. Relatório interno do Projeto MADAM, 2002

GOMES,R.KS. PEREIRA.C.C.P， RIBEIRO， C.M.M， COSTA,R.M. Dinâmica Socioambiental em uma comunidade amazônica pesqueira, PA-Brasil, Revista da Gestão Costeira Integrada, UNIVALI, 2010.

GOES, M. H. B. Ambientes Costeiros do Estado de Alagoas. Dissertação de Mestrado em Geografia, Universidade Federal do Rio de Janeiro, RJ,1979.

HAESBAERT, R. O mito da desterritorialização e as "regiões-rede". Anais do V Congresso Brasileiro de Geografia. Curitiba: AGB, pp. 1004, 206-214.

EdUFF, 1997.

Des-territorialização e Identidade: a rede "gaúcha" no Nordeste. Niterói:

Da desterritorialização à multiterritorialidade. Anais do IX Encontro Nacional da ANPUR. Vol. 3. Rio de Janeiro: ANPUR, 2001ª . 
Le mythe de la déterritorialisation. Géographies et Cultures n. 40. Paris: L'Harmattan.2001b.

A multiterritorialidade do mundo e o exemplo da Al Qaeda. Terra Livre n. 7.

São Paulo: Associação dos Geógrafos Brasileiros. 2002a

Fim dos territórios ou novas territorialidades? In: Lopes, L. e Bastos, L. (org.) Identidades: recortes multi e interdisciplinares. Campinas:

Mercado de Letras.2002b.

O mito da desterritorialização: do "fim dos territórios" à multiterritorialidade. Rio de Janeiro: Bertrand Brasil. 2004.

LEFF, E. Saber Ambiental: sustentabilidade, complexidade, poder. Petrópolis, RJ: Vozes, 2001.

Ecologia, capital e cultura: a territorialização da racionalidade ambiental. Trad. Jorge . E. Silva. Vozes: Petrópolis, RJ, 2009.

McDOUGALL, D. The visual in anthropology. In: Visual antropology London: Yale University Press, 1997.

MANESCHY, M.C. Ajuruteua, uma comunidade pesqueira ameaçada. 1edição. Editora Universitária Belém-PA: UFPA, 1995.

MAUES, R.H. Origens históricas da cidade de Bragança, Revista de História, São Paulo, 1967.

MELLO, A.B.F. A pesca sob o capital, a tecnologia a serviço da denominação. Belém: UFPA, 1985.

MORAES, A.C.R.. Contribuições para a Gestão da Zona Costeira do Brasil. São Paulo: Hucitec/EDUSP, 1999.

MOREIRA, R.. O que é Geografia. São Paulo: Brasiliense, 1985. Coleção Primeiros Passos.

NASH, A.D. Impacts of marine debris on subsistence fishermen, an exploratory study. Marine Pollution Bulletin, 1992.

NEVES. J.L. Pesquisa Qualitativa: características, usos e possibilidades. Caderno de pesquisa em administração. São Paulo. V1. N.03, 2º Semestre, 1996.

PENTEADO, A.R. Problemas de colonização e uso da terra na região bragantina do Estado do Pará. Belém: UFPA, 1967.

PRIMACK. R.; RODRIGUES. E. Biologia da conservação. São Paulo-SP: Ed. Planta, 2002.

PROJETO ORLA. Subsídios para um projeto de gestão / Brasília: MMA e MPO, 2004. (Projeto Orla). 
RICKETTS, P. J. National policy and management responses to the hazard of coastal erosion in Britain and the United States. Applied Geography, v. 6, p. 197-221, 1986.

RUSCHMANN, D. V. M. Turismo e planejamento sustentável: a proteção do ambiente. Campinas, Papirus, 1997.

SACK, R. D. Human territoriality: its theory and history. Cambridge: Cambridge University, 1986

SANTOS, M. Técnica, espaço, tempo: globalização e meio técnico - científico informacional. São Paulo: HUCITC, 1994.

SANTOS, M.A.S, A cadeia produtiva da pesca artesanal no Estado do Pará: estudo de caso no Nordeste Paraense. Amazônia, Belém, v. 1, n. 1, p. 61-81, 200.

SANTOS. J.L. O que é Cultura. São Paulo: Brasiliense, 2012. Coleção Primeiros Passos.

SILVA, A. P.R; FERNANDES. J. G.S.; FEITOSA. R.S. (ORGS.). A reserva extrativista marinha Caeté-Taperaçu/Bragança-PA. PPGLS, PROEX, UFPA, 2012.

SOUZA FILHO, P.W.M. Influências das variações do nível do mar na morfoestratigrafia na Planície Costeira Bragantina durante o Holoceno, 1995. Dissertação de Mestrado. Belém-Pará: UFPA, 1995.

WAGLER, C. Uma comunidade amazônica: estudo do homem nos trópicos. São Paulo. Ed.Nacional, 1975. 